\title{
Islamic Perspective
}

\section{Human Genetics and Islam: Scientific and Medical Aspects}

\author{
Bilal A.A. Ghareeb, PhD \\ Associate Professor, Department of Biology and Biotechnology, \\ Arab American University-Jenin (AAUJ) \\ Jenin, Palestine
}

\begin{abstract}
:
Objective: To relate diverse aspects of genetics and its applications to concepts in the Glorious Qur'an and the hadith.

Study Design: The author compared passages from the Glorious Qur'an and hadith with modern concepts in genetics, such as recessive inheritance, genetic counseling, genetic variation, cytoplasmic inheritance, sex chromosomes, genetics-environment interactions, gender determination, and the hypothesis of "pairing in the universe."

Conclusions: A fresh understanding of Islamic scripture reveals references to principles of genetics that predate contemporary discoveries. This highlights the need for further exploration of possible links between science and religion.
\end{abstract}

Key words: Qur'an, hadīth, genetics, genetic counseling, recessiveness, cytoplasmic inheritance, epigenetics, gender determination.

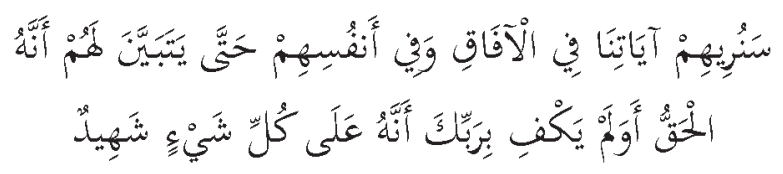

Soon We will show them Our signs in the (furthest) horizons (of the universe) and their own souls, until it becomes manifest to them that this is the Truth. Is it not enough that your Lord witnesses all things?

Introduction

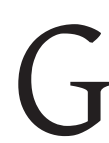
enetics is the study of genes and the principles and mechanisms of heredity, or the means by which traits are passed from parents to offspring. ${ }^{2,3}$ The scientific field of genetics can help families affected by genetic disorders better understand them and possible strategies to decrease their incidence. From the perspective of the faithful, sci-

Correspondence should be directed to

Bilal A.A. Ghareeb, PhD

email:bilalghareeb@yahoo.com ence and religion should be intrinsically compatible. While science attempts to describe the reality and mechanisms of creation, only the Creator, God dist, is the All-Knowing. This paper focuses on the science of genetics and applying it to our lives with an Islamic perspective.

\section{Methodology}

The Glorious Qur'an and the reports about the Messenger Muhammad علئلس (hadith, pl ahädìth) were screened for useful links to modern genetics. Specifically, the sacred texts were searched for the key words in Table 1. The Glorious Qur'an was scanned by manual reading. Narrations of hadith were searched for the same key terms using the online database at dorar.net and then subsequently verified using the online database at muhaddith.org.

\section{Recessive Inheritance and Genetic Counseling}

An allele is an alternative version of a gene that produces a distinguishable phenotypic effect. Mendel worked on peas and coined the terms "dominant" 
and "recessive" traits, which are used to describe alleles. Mendelian laws of heredity are applicable to plants, animals, and humans. Alleles segregate in gametes. Haploid cells, such as an ovum or sperm, contain only one copy of a chromosome pair carrying one allele. Gametes unite during sexual reproduction to produce a diploid zygote (the fertilized egg), which contains two copies of each chromosome and hence the two alleles. In autosomal inheritance, both alleles of a gene have to be recessive to express the recessive phenotype whereas only one dominant allele is sufficient for the expression of a dominant phenotype. This also means that a recessive allele may be masked by a dominant allele in one generation but reappear in a subsequent generation.

In the following hadith, the word 'irq seems to approximate this concept.

$$
\begin{aligned}
& \text { جاء رجل من بني فَزَرَارة إلى النبي فقال إن امرأتي ولدت }
\end{aligned}
$$

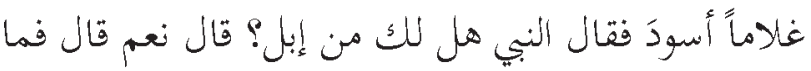

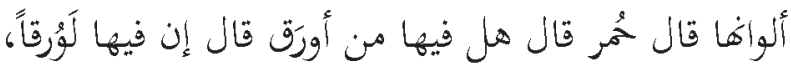

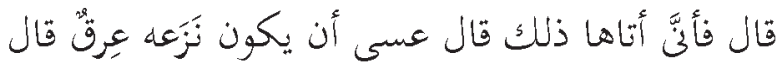

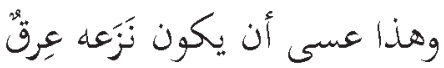

There came a person to the Prophet aلd ellede from Banu Fazara and said: My wife has given birth to a child who is black, whereupon Allah's Apostle aلdugande said: Have you any camels? He said: Yes. He again said: What is this [sic: read their] colour? He said: They are red. He said: Is there a dusky one among them? He said: Yes, there are dusky ones among them[.] He said: How has it come about? He said: It is perhaps the strain ('irq) to which it has reverted, whereupon he (the Prophet) said: It is perhaps the strain ('irq) to which he (the child) has reverted. 4,5

Islam advocated justice and human rights. It is genetically possible for two parents with lighter complexions to bear a dark-complexioned child. Understanding genetic possibilities could prevent false accusations of paternity and consequent abuse of innocent people, especially women.

Genetic counseling advises patients or relatives at risk of an inherited disorder or a trait of the con-
Table 1. Arabic search terms and their corresponding English translations.

\begin{tabular}{|c|c|c|c|}
\hline Parents & أباء & Inherit & ورث \\
\hline \multirow[t]{2}{*}{ Womb } & a & Deliver & وند \\
\hline & بطن الأم & Mates & أكفاء \\
\hline Male & زكر & Semen & سائل هنوي \\
\hline \multirow[t]{2}{*}{ Female } & أنثى & Mother & أُم \\
\hline & & Father & أب \\
\hline
\end{tabular}

sequences and nature of the disorder or character, the probability of developing or transmitting it, and the options available in order to prevent, avoid, or ameliorate it. This complex process can have diagnostic (the estimation of risk) and supportive aspects. ${ }^{6}$

Prophet Muhammad allugade probably had an intuitive understanding that some traits inherited from the parents were apparent in ancestral generations but not in the parents. This concept underlies our current understanding of dominant and recessive inheritance. In the following hadith, he recommended that a person should carefully select his or her mate. The word 'irq could mean traits or genes, while the word dassās is probably used to designate the behavior of human traits that skip a generation but reappear in the next.

$$
\text { تخيروا لنطفكم فإن العرق دساس }
$$

Choose well your mate (for your semen) as

(the hidden) traits can reappear. ${ }^{7}$

This hadith implies that 'irq or gene is not only implicated in simple traits like skin color as in the first hadith but are also implicated in the whole range of hereditary traits including character and disease.

\section{Natural Selection}

A verse from the Glorious Qur'an mentions that man is created from an extract, sulāla, of a liquid:

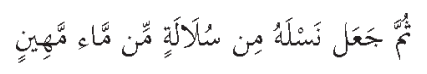

Then He made his progeny of an extract of water (liquid) held in light estimation. ${ }^{8}$ 
Furthermore, Prophet Muhammad aلd alle stated in a hadith that only part of the seminal fluid participates in the fertilization process.

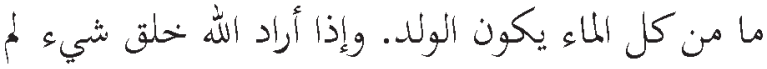

$$
\begin{aligned}
& \text { يمنعه شيء }
\end{aligned}
$$

Not from all the liquid comes the child. And if Allah wants to create something, nothing prevents Him.9-10

This hadith appears in discussions regarding the permissibility of 'azl (coitus interruptus or withdrawal method), a form of contraception that the ancient Arabs knew. Most commentators understood this passage to mean that not every instance of sexual intercourse results in pregnancy. The alternate meaning of the divisibility of the seminal fluid is also linguistically possible, and recent scientific knowledge adds to this interpretation's probability.

These statements from more than 1,400 years ago were confirmed in the modern era. Only one sperm out of hundreds of millions released during copulation fertilizes the ovum. In fact, the great majority of sperm die during their travel toward the ovum. At the end of this voyage, around 500 sperms reach the ovum. This minority must be the most motile to compete for the penetration of the ovum.

This form of natural selection before fertilization takes place not only with sperms but also with ova. A female has at the beginning of her fetal life about six million primary oocytes, diploid cells containing two sets of chromosomes, many of which degenerate before birth. Approximately, 30,000 primary oocytes remain at birth and then begin to mature after menarche at a frequency of just one or very few per every menstrual cycle. The mature secondary oocytes or ova are haploid cells, containing half the chromosomal number as a result of meiotic division. On average, only 400 mature ova capable of being fertilized develop during a female's lifetime.

As part of the natural selection process, genetic variation is ensured partly due to the wide range of probable chromosomal crossovers and recombinations. For example, the total number of possible combinations of chromosomes present in human gametes is $2^{23}$, where 23 is the total number of chromosome pairs or $\sim 8 \times 10^{6}$ possible combinations. Accordingly, after fertilization of a human ovum by a sperm, the resulting diploid zygote may be produced theoretically with any of 64 trillion $\left(2^{23} \times 2^{23}\right)$ possibilities of chromosomal pairings. The possibilities are multiplied due to the randomness of the fertilization process in addition to the process of crossing over. ${ }^{11}$

Natural selection also continues after conception. Up to $78 \%$ of pregnancies may be spontaneously aborted. Half of these occur without the knowledge of the mothers, who think the bleeding resulting from the spontaneous abortion is menstrual blood. ${ }^{12}$ The great majority of these early unrecognized miscarriages are due to chromosomal abnormalities, which are mostly due to abnormalities in meiosis in the female. Meiosis begins during the third month of a female's fetal life and continues throughout maturity. As time progresses and the age of the mother increases, meiotic division seemingly becomes disturbed and may produce abnormalities (dysjunction) that result in an abnormal number of chromosomes. If this affects autosomal chromosomes, it results in syndromes such as Downs syndrome (trisomy 21), trisomy 13 or trisomy 18. If it affects sex chromosomes, it results in syndromes such as Turner or Klinefelter. These abnormalities may also come from the father's side as a result of faulty meiotic division during spermatogenesis. These are not correlated with the father's age, as meisos in males is brief, about 72 hours, compared to years in females. ${ }^{2}$ As a result of all these factors, probably only $1 \%$ of acts of sexual intercourse result in a conception leading to a viable offspring, and this represents a significant process of natural selection.

\section{Cytoplasmic Inheritance, Sex Chromosomes and Beneficence to Parents}

In Islam, both parents are worthy of beneficence:

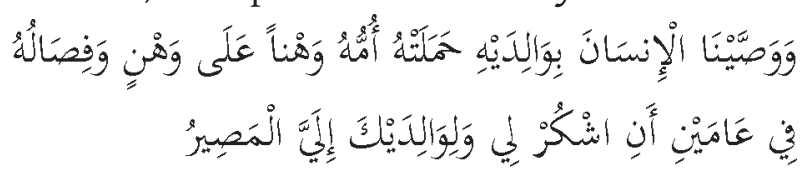

And We have enjoined man in respect of his parents - his mother bears him with faintings upon faintings and his weaning takes two years - saying: Be grateful to Me and to both your parents; to Me is the eventual coming. 13

Interestingly, however, the above verse gives moth- 
ers priority over fathers. This principle is confirmed in a hadith where Muslims are instructed to give their mothers three-fold beneficence, respect and caring as compared to their fathers. This should be, at least partially, a matter of compensation for the intensive care that offspring receive from their mothers. The special elevated rank of mothers is alluded to in the following hadith:

$$
\begin{aligned}
& \text { سُئل رسول الله من أحق الناس بحسن صحابتي قال أملك } \\
& \text { قال تم من قال تم أملك قال ثم من قال ثم أملك قال ثم من } \\
& \text { قال ثم أبوك }
\end{aligned}
$$

A man came to Allah's Apostle and said, "O Allah's Apostle! Who is more entitled to be treated with the best companionship by me?" The Prophet said, "Your mother." The man said. "Who is next?" The Prophet said, "Your mother." The man further said, "Who is next?" The Prophet said, "Your mother." The man asked for the fourth time, "Who is next? The Prophet said, "Your father"14,15

It is noteworthy that regardless of the offspring's sex, cytoplasmic inheritance is exclusively maternal. Actually, cytoplasm contains exclusively maternally inherited mitochondria, which harbor tiny circular DNA molecules that contain 37 of our genes. The genetic balance is, therefore, in favor of mothers. ${ }^{16-7}$ In addition, this is especially true in male offspring who inherit their long sex chromosome $X$ from their mothers but their short sex chromosome $Y$ from their fathers. The $\mathrm{X}$ chromosome is much larger (154,913,754 base pairs versus $57,741,652$ base pairs) and contains many more genes (1,846 versus 454 ) than the $\mathrm{Y}$ chromosome. This results in more maternal than paternal genetic participation in our development.

In addition to the extra genetic material, organelles such as mitochondria, mRNA molecules, and other determinants present in the cytoplasm of unfertilized oocytes are transmitted to the zygote. These maternal cytoplasmic determinants play a capital role in the differentiation of zygotic cells into the many differentiated cell types through the expression of the appropriate gene(s) in each type of cell. They also determine the body plan and orientation of the embryo. ${ }^{11}$
Therefore, in addition to the long period of pregnancy, labor, hard delivery, breast-feeding, and continuous care given, mothers contribute more genetic material to their offspring than fathers. Maternal determinants guide embryos towards appropriate body orientation and differentiation. ${ }^{11}$ Mothers have an extraordinary rank in Islam due to their contributions to life and society. Perhaps Islam also recognizes their contributions to biology and genetics.

\section{Genetics-Environment Interactions}

Genetics is concerned with genes inherited from parents, while environment encompasses all the external factors that influence organisms directly or indirectly. For most human characteristics, including those exhibited during health and disease, genes and environment interact to produce the phenotype. ${ }^{18-9}$ A minority of diseases are caused by a single defective gene, e.g. Huntington disease. However, the majority of diseases are caused by multiple defective genes and environmental components that influence the appearance and severity of those diseases. Examples of such diseases include cancer, heart disease, and diabetes.

Similarly, epigenetic alterations that affect human behavior may result from interactions with the environment.20-3 Epigenetic changes do not directly alter nucleotide sequences but may rather affect genomic architecture (chromatin folding and attachment to the nuclear matrix, packaging of DNA around nucleosomes) and appendages (covalent modifications of histone tails by acetylation, methylation, phosphorylation, as well as DNA methylation). ${ }^{11}$ Cellular epigenetic mosaicism and phenotypic differences are reported in genetically identical twins. ${ }^{23-4}$ Convincing evidence on the effect of environment on genetic expression comes from studies on mice that reported epigenetic alterations through DNA hypomethylation after exposure to BishphenolA during early development. ${ }^{24}$ Childhood abuse has also been shown to result in epigenetic changes in the glucocorticoid receptor, and alteration of genetic expression in the brain was associated with suicide. ${ }^{22}$

Human psychology is determined by multiple factors and influences. The environment of the womb, with all its biological, chemical, and physical components, evidently has an important impact on the embryo's developing character. 


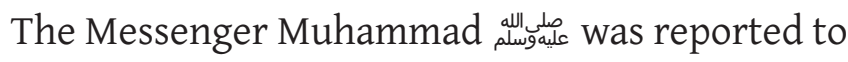
have said:

$$
\text { الشقي من شقي في بطن أمه والسعيد من سعد في بطنها }
$$

The misfortunate one is who became misfortunate in the womb and the happy is the one who became happy in the womb. 25

This text and similar ones have been interpreted to refer to the individual's salvation in paradise or punishment in hell. The phrase batn ummihi (womb), when compared with other texts, should be interpreted metaphorically to indicate the time before a person's birth. In any case, it may also support the concept that environmental factors may affect the development, character and traits of the fetus in its mother's womb, and that this may result in the child's happiness and misery in this life. The mentioning of this word, batn ummihi, the emphasis Islam places upon the rights of children on their guardians and the lengthy discussions Muslim jurists have had in the topic of the care of minors (hadāna) should cause Muslims, in light of the recent scientific discoveries mentioned above, to strive to improve maternal health care.

\section{Gender Determination}

The Qur'an clearly states that both men and women contribute to the creation of offspring:

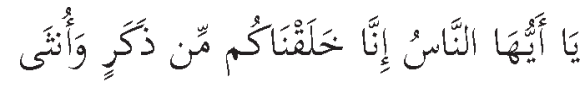

O you people! surely We have created you from a male and a female. ${ }^{26}$

Another verse talks about mingled nutfa (drops of fluid) as the beginning of human creation, implying the contribution of both male and female fluids.

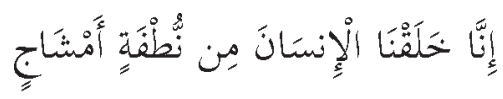

We created humans from a drop of mingled fluid. ${ }^{27}$

These two verses indicate both male and female involvement in the formation of the embryo. However, does the father or the mother determine the gender of the offspring? In an authentic hadith

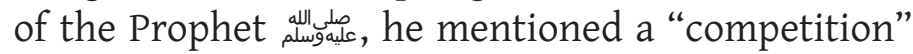

between the male seminal fluid and the female reproductive fluid vis-à-vis the determination of gender:

$$
\begin{aligned}
& \text { ماء الرجل أبيض و ماء المرأة أصفر فإذا الجتمعا فَعلا مَتِيُّ }
\end{aligned}
$$

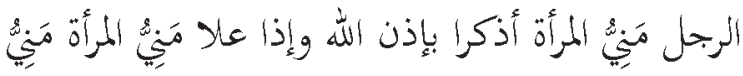

$$
\begin{aligned}
& \text { الرجل آنثا بإذن الله }
\end{aligned}
$$

The reproductive substance of man is white and that of woman is yellow, and when they have sexual intercourse and the male's substance prevails upon the female's substance, it is a male child that is created by Allah's decree, and when the substance of the female prevails upon the substance contributed by the male, a female child is formed by the decree of Allah. ${ }^{28-9}$

Another hadīth states:

$$
\begin{aligned}
& \text { فإن الرجل إذا غشي المرأة فسبقها ماؤه كان الشبه له وإذا } \\
& \text { سبق ماؤها كان الشبه هل }
\end{aligned}
$$

If man's liquid (semen) prevails over the liquid of woman, the child will resemble his father. If the woman's liquid prevails over his liquid, then the child will resemble her. ${ }^{30}$

Consequently, gender is determined by a necessary interaction between paternal and maternal components. How can this be reconciled with the classical concept that the father determines the gender of the child by contributing the male-determining Y-chromosome to his offspring? The answer to this question could include the favoring of either $\mathrm{X}$ or Y-bearing paternal gametes by the prevailing environmental condition in the woman's reproductive tract. Could the competition referred to in the above ahadith relate to the difference in the $\mathrm{pH}$ of the seminal and vaginal fluids?

The $\mathrm{pH}$ of the seminal fluid differs from that of the reproductive secretions of females. A woman's vaginal $\mathrm{pH}$ ranges from 4.5 to 4.7 (acidic). ${ }^{31}$ In contrast, the normal $\mathrm{pH}$ of semen ranges between 7.2 and 7.8 (alkaline). ${ }^{32}$ Thus the ahādith may suggest that the more alkaline medium favors male and the more acidic medium favors female offspring. Genetic studies in fish have reported an effect of $\mathrm{pH}$ on gender determination. For example, in broods of 
Pelvicachromis fishes (kribensis and relatives), acidic water favors males, and alkaline water favors females. ${ }^{33-4}$ Acidity also favors the development of males in other species of fishes such as Apistrogramma cacatuoides, A. gephyra, A. hongsloi, A. nijsseni. The discrepancy between the presumed effect of observed $\mathrm{pH}$ differences in human reproductive fluids based on the interpretation of these ahadith and the studied fishes indicate that other factors may influence the role of $\mathrm{pH}$ in gender determination or that there are other physical, chemical, or physiological characteristics in the male and female reproductive fluids that favor the formation of one gender of the embryo over the other.

In some fish species, other environmental factors such as temperature, hormones, and social conditions influence gender determination. Extreme environmental treatments can even "override" the genetic basis of sex. Genetically-female Poecilia reticulata, for example, will mature as males if raised in extreme temperatures. ${ }^{35-6}$ Higher temperatures also are found to favor producing more males. The effects of temperature and $\mathrm{pH}$ are, however, not "all-ornone," i.e., not even high temperature and low $\mathrm{pH}$ together will effectively produce $100 \%$ males. ${ }^{37}$ Nevertheless, these observations are interesting and warrant further investigation to determine whether an environmental factor, such as $\mathrm{pH}$ or temperature, has a role in determination of the gender of the human fetus.

Compatible with the role of the environment discussed above, recent studies have shown that maternal nutrition influences gender determination of the child. A wide range of nutrients, including potassium, calcium (elements that favor an alkaline environment) and vitamins C, E and B12, enhance begetting of boys in contrast to a low-caloric diet, which enhances begetting of girls. ${ }^{38}$ Such studies demonstrate, effectively, that women also play a role in the determination of the offspring's gender. This seems to diverge from the hypothesis in classical genetics that gender determination in humans could be attributed only to the father.

In summary, the previously mentioned sacred verses and ahädìth as well as recent scientific literature can lead us to appropriately conclude that while the father is responsible for genetic determination of the child's gender, the environment of the female genital tract may influence the child's gender.
Specifically, the physical, chemical, or physiological characteristics of reproductive fluids and the nutrition of the mother may be considered environmental determinants of gender.

\section{Hypothesis of "Pairing in the Universe" in the Glorious Qur'an}

Pairing, which is the combination of opposites such as males and females or positive and negative, is a general phenomenon found in nature. The pairing or parity phenomenon is also well known in molecular genetics as in the examples of the double helical structure of DNA and the composition of double stranded RNA molecules.39-40 The Glorious Qur'an evoked this general phenomenon of pairing in a couple of verses:

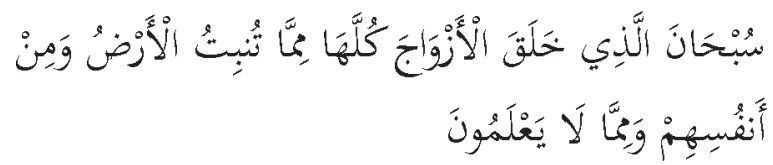

Glory be to Him Who created pairs of all things, of what the earth grows, and of their kind and of what they do not know. ${ }^{41}$

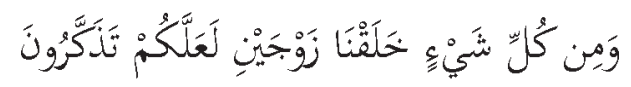

And of everything We have created pairs that you may be mindful. 42

British physicist Paul Dirac, who discovered that matter was created in pairs, won the Nobel Prize for Physics in 1933. This finding, known as "parity," revealed the duality known as matter and antimatter. Antimatter bears the opposite characteristics to matter. For instance, contrary to matter, antimatter electrons are positive and protons negative. This fact is expressed as follows: “... every particle has its antiparticle of opposite charge... The uncertainty relation tells us that pair creation and pair annihilation happen in the vacuum at all times, in all places." 43

\section{Conclusions and Perspectives}

The linking of texts of the Glorious Qur'an and the Prophetic tradition to recent scientific discoveries is a reflection of the additional meanings Muslim scientists may suggest for these texts. However, it must be emphasized that the Qur'an and the Prophetic tradition are foremost sources for human guidance and not sources of scientific knowledge. 
Nevertheless, this paper stresses the need for further investigation of genetic discoveries such as environmental factors that influence gender determination or pairing in the universe that can be inspired from the Glorious Qur'an. These investigations would encourage seeking the science and knowledge of creation, a religious obligation for the believer:

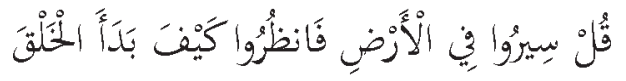

Say: Travel in the earth and see how He started the creation. ${ }^{4}$

\section{Acknowledgments}

All thanks are ultimately to Allah alle who guides us in this life. Many thanks are addressed to the following colleagues and friends: Dr. Saeed Rahbania, and Dr. Mohammad Dawabsheh for their helpful linguistic revision of English and Arabic, respectively, as well as to their kind and useful remarks. Many thanks go as well to Prof. Hilmi Abdel-Hadi, Dr. Abdel-Rahman Abu-Labdeh, Mr. Abdessalam Kmeil, Dr. Taleb Kheir-el-Deen, and Mr. Ahmad Risheq for their useful remarks.

\section{References}

1. The Glorious Qur'an, Chapter 41, Verse 53.

2. Griffiths AJF, William M, Miller et al. An introduction to genetic analysis. 7th ed. New York: W. H. Freeman; 2007.

3. Glanze W (ed.). The signet Mosby medical encyclopedia (revised edition). New York: Penguin Books Ltd.; 1996.

4. Șaḥị Muslim. Kitāb al-Lì ān. Hadīth no. 1500. Available from muhaddith.org

5. Sahih Muslim. Siddiqui AH (translator). Book 9, Number 3574. http://www.cmje.org/religioustexts/hadith/muslim/009-smt.php

6. Cassiman JJ. Research network: EuroGentest-a European network of excellence aimed at harmonizing genetic testing services. Eur J Hum Genet. 2005;13:1103-5.http://doi.org/g4c

7. 'Abd al-Rahīm b. al-Ḥusayn b. `Abd al-Raḥmān aka al-Ḥāfiz Al-'Irāqī. Takhrīj ahādīth al-ihyā'. Vol 2, Chapter 2: Fīmā yurā̄à hāla al-'aqd. hạadìth No. 4. http://muhaddith.org

8. The Glorious Qur'an, Chapter 32, Verse 8.

9. Șahīh Muslim. Kitāb Al-Nikah Bab Hukm Al-'Azl. http://muhaddith.org
10. Șahịh Muslim. Siddiqui AH (translator). Book 8, Number 3381. http://www.cmje.org/religioustexts/hadith/muslim/008-smt.php

11. Campbell NA, Reece JB, Mitchell LG. Biology, 8th edition. Mento Park, California: Addisson-Wesley Longman Publisher; 2008.

12. Al-Bar MA. Khalq al-insān bayn al-țibb wa alQur'ān. 8th ed. Jadda: Al-Dar Al-Sa'ūdiyya li al-nashr wa al-tawzì̀ ; 1991.

13. The Glorious Qur'an, Chapter 31, Verse 14.

14. Saḥịh al-Bukhārī. Kitāb al-Adab. Bāb man aḥaqq al-nās bi husn al-suḥba. Hadith no. 5626. http://muhaddith.org

15. Saḥị al-Bukhārī. Khan MM (translator). Volume 8, Book 73, Number 2. http://www.cmje.org/ religious-texts/hadith/bukhari/073-sbt.php

16. Chan DC. Mitochondria: dynamic organelles in disease, aging, and development. Cell. 2008; 125:1241-52. http://doi.org/bcsbj4

17. Birky CW Jr. Relaxed and stringent genomes: Why cytoplasmic genes don't obey Mendel's laws. J Hered. 1994;85:355-65.

18. Jaffee SR, Price TS. Gene-environment correlations: a review of the evidence and implications for prevention of mental illness. Molecular Psychiatry. 2007;12:432-42. http://doi.org/g4d

19. Khoury MJ, Davis R, Gwinn M, et al. Do we need genomic research for the prevention of common diseases with environmental causes? Am J Epidemiol. 2005;161:799-805.http://doi.org/g4f

20. Plomin R, DeFries JC, Loehlin JC. Genotype-environment interaction and correlation in the analysis of human behavior. Psychol Bull. 1977;84:309-22. http://dx.doi.org/10.1037/0033-2909.84.2.309

21. Cadoret RJ, Cain CA, Crowe RR. Evidence for geneenvironment interaction in the development of adolescent antisocial behavior. Behav Genet. 1983;13:301-10. http://doi.org/g4g

22. McGowan PO, Sasaki A, D'Alessio AC, et al. Epigenetic regulation of the glucocorticoid receptor in human brain associates with childhood abuse. Nat Neurosci. 2009;12:342-8. http://doi.org/g4h

23. Dolinoy DC, Huang D, Jirtle RL. Maternal nutrient supplementation counteracts bisphenol A-induced DNA hypomethylation in early development. Proc Natl Acad Sci. 2007;104:13056-61.http://doi.org/g4j 24. Dolinoy DC. The agouti mouse model: an epigenetic biosensor for nutritional and environmental alterations on the fetal epigenome. Nutr Rev. 
2008;66(Suppl.1):S7-S11.http://doi.org/g4k

25. 'Abd al-Ḥaqq al-Ishbīlī. Al-Ahkām el-shar' iyya alkubrā. Husayn ibn 'Ukāsha (ed.). Riyadh:Maktabat alRushd; $1422 \mathrm{AH}$.

26. The Glorious Qur'an, Chapter 49, Verse 13.

27. The Glorious Qur'an, Chapter 76, Verse 2.

28. Șahịh Muslim. Kitāb al-ḥayḍ. Bāb bayān șifa maniyy al-rajul wa al-mar'a wa anna al-walad makhlūq min mā'ihimā. Hadith no. 315. http://muhaddith.org

29. Șahịh Muslim. Siddiqui AH (translator). Book 3, Number 614. http://www.cmje.org/religioustexts/hadith/muslim/003-smt.php

30. Saḥị̣ al-Bukhārī. Kitāb al-anbiyā'. Bāb qawl Allah ta'ālā. Hadith no. 3151. http://muhaddith.org

31. Ferris DG, Francis SL, Dickman FD, et. al. Variability of vaginal $\mathrm{pH}$ determination by patients and clinicians. J Am Board Fam Med. 2006;19:368-73. http://doi.org/g4m

32. State University of New York - Stony Brook [web site]. Sheynkin YR. Understanding semen analysis. h t t p: / / w w w . uh m c.sun y s b.edu/ urology/male infertility/SEMEN ANALYSIS.html. [Last updated 2000-Mar-22; Accessed 2011-05-31]. 33. Rubin DA. Effect of $\mathrm{pH}$ on sex ratio in cichlids and a poeciliid (Teleostei). Copeia. 1985;233-5. http://dx.doi.org/10.2307/1444818

34. Heiligenberg W. Colour polymorphism in the males of an African cichlid fish. Proceedings of the Zoological Society of London. 1965;146:95-7. http://doi.org/g4n

35. Francis RC. Sexual lability in teleosts: developmental factors. Q Rev Biol. 1992;67:1-18. http://dx.doi.org/10.1086/417445

36. Coleman RM. Cichlids and science: sex determination. Cichlid News. 1997;6:20-1.

37. Römer U, Beisenherz W. Environmental determination of sex in Apistogrammai (Cichlidae) and two other freshwater fishes (Teleostei). J Fish Biol. 1996;48:714-25.http://doi.org/g4s

38. Mathews F, Johnson PJ, Neil A. You are what your mother eats: evidence for maternal preconception diet influencing foetal sex in humans. Proc Biol Sci. 2008:275;1661-8. http://doi.org/g4p

39. Watson JD, Crick FHC. A Structure for Deoxyribose Nucleic Acid. Nature 1953; 171(4356):737-8. http://doi.org/g4q

40. Macrae I, Zhou K, Li F, et al. Structural basis for double-stranded RNA processing by dicer. Science 2006;311(5758): 195-8.http://doi.org/g4r

41. The Glorious Qur'an, Chapter 36, Verse 36.

42. The Glorious Qur'an, Chapter 51, Verse 49.

43. Genz H. Nothingness: the science of empty space. Reading, Massachusetts: Perseus Books Publishing, L.L.C.; 1999.

44. The Glorious Qur'an, Chapter 29, Verse 20. 